\title{
CD82 Gene
}

National Cancer Institute

\section{Source}

National Cancer Institute. CD82 Gene. NCI Thesaurus. Code C18459.

This gene plays a role in the regulation of membrane receptor functions. 